\title{
Badania mineralizacji REE w utworach pokrywy osadowej masywu Tajna
}

\author{
Witold Dymowski ${ }^{1}$
}

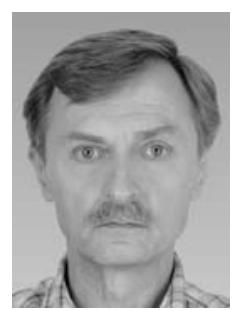

REE mineralization in the sedimentary cover of the Tajno Massif, NE Poland. Prz. Geol., 69: 426-433; doi: $10.7306 / 2021.26$

A b s tr a c t. The paper presents a study of occurrences of REE mineralization in Lower Triassic and Middle Jurassic sedimentary rocks in the Tajno Massif, NE European Platform. Manifestations the REE mineralization occur in siltstones, sandstones, conglomerates and debris, and in other mixed weathered rocks.

Keywords: REE mineralization, Lower Triassic, Middle Jurassic, Tajno Massif

Na początku lat $60 . \mathrm{XX}$ w. w wyniku badań podłoża krystalicznego NE Polski metodami geofizycznymi ujawniono występowanie w rejonie Suwałk dużych złóż rud żelaza (Znosko, 1993). Sprawdzając kolejne anomalie magnetyczne i grawimetryczne, natrafiono wierceniami na skały ultrazasadowo-alkaliczne z żyłami karbonatytowymi i impregnacjami, wzbogacone $\mathrm{w}$ mineralizację pierwiastków ziem rzadkich (Ryka, 1992; Ryka i in., 1992). Przebadanie mineralogiczno-petrograficzne i złożowe masywów Ełku i Tajna doprowadziło do oszacowania zasobów pierwiastków ziem rzadkich (REE) w złożu Tajno. Ostatnio podjęto badania w celu sprawdzenia, czy zwietrzeliny krystalicznych skał masywu Tajna zawierających złoże REE, głównie plutonicznych i wulkanicznych, zasiliły w nie utwory spagu pokrywy osadowej.

\section{OBSZAR BADAŃ}

Badania prowadzono w masywie Tajna na platformie wschodnioeuropejskiej. Masyw ten jest usytuowany kilkanaście kilometrów na południe od Augustowa. Wyróżnia się w nim dwa piętra strukturalne - prekambryjskie (lokalnie staropaleozoiczne) podłoże krystaliczne oraz mezozoiczno-kenozoiczną pokrywę osadową (ryc. 1).

W rejonie Tajna strop fundamentu krystalicznego występuje na głębokości ok. 585-600 m. Na zwietrzelinie utworów krystalicznych płasko zalegają dolnotriasowe pstre skały klastyczne (ilasto-mułowcowo-piaszczyste) o miąższości kilku do kilkunastu metrów (Gaczyński, Szymański, 1967), lokalnie występują one płatami. Przykrywają je miąższe osady środkowo- i górnojurajskie (w tym jasne piaskowce i mułowce bajosu-batonu) oraz górnokredowe. Wyżej są obecne osady paleogenu, neogenu i czwartorzędu o mniejszej miąższości (Gaczyński, Szymański, 1967).

\section{ZAKRES I METODYKA BADAŃ}

Do badań wytypowano trzy rdzenie otworów wiertniczych: Tajno IG 3, Tajno IG 5 i Tajno IG 11, najlepiej zachowane spośród 10 pochodzących z masywu Tajna. Z tych trzech rdzeni pobrano 24 próbki skał: 11 próbek ze stropu krystaliniku, 7 próbek z utworów dolnego triasu i 6 próbek ze środkowej jury, po czym poddano je szczegółowym obserwacjom makroskopowym. Ze względu na mały uzysk rdzenia, miejscami ograniczony do kilkunastu, a nawet tylko kilku procent, nie można było precyzyjnie określić, z jakiej głębokości pochodziły pobrane próbki skał, możliwe było jedynie wskazanie przedziałów głębokości ich występowania. $\mathrm{Z}$ tego samego powodu dokonano jedynie ogólnego podziału litostratygraficznego skał osadowych. Do ich korelacji wykorzystywano także charakterystyczne krzywe karotażowe.

Do chemicznych badań skał i mineralizacji śladowej, w tym pełnego spektrum pierwiastków ziem rzadkich (REE), wytypowano jedynie 18 próbek o różnej litologii. Najwięcej próbek przeznaczonych do badań (11 sztuk) pochodziło z otworu Tajno IG 11 o najlepiej zachowanym rdzeniu i najpełniejszym profilu utworów spagu pokrywy osadowej. Jako odnośnik poziomu tła dobrano jeszcze pojedyncze próbki z utworów jurajskich oraz gnejsów z otworu Tajno IG 5 ( 5 szt.) i Tajno IG 3 (1 szt.). Próbki pobierano w kolejności od stropu klastycznych utworów triasu (głównie dolnego), poprzez zwietrzeliny różnej frakcji, aż do zlepieńców i brekcji czy rumoszów oraz zwietrzałych skał podłoża krystalicznego.

Analizy chemiczne skał wykonano w Centralnym Laboratorium Chemicznym PIG-PIB w 2019 r. Skład pierwiastków głównych (próbek stapianych): $\mathrm{SiO}_{2}, \mathrm{Al}_{2} \mathrm{O}_{3}$, $\mathrm{K}_{2} \mathrm{O}, \mathrm{TiO}_{2}, \mathrm{MnO}, \mathrm{Fe}_{2} \mathrm{O}_{3}, \mathrm{Na}_{2} \mathrm{O}, \mathrm{CaO}, \mathrm{MgO}, \mathrm{P}_{2} \mathrm{O}_{5}, \mathrm{SO}_{3}, \mathrm{Cl}$ oraz $\mathrm{F}$, określono metodą fluorescencyjnej spektrometrii rentgenowskiej $\mathrm{z}$ dyspersją fali (WD-XRF). Zawartość pierwiastków śladowych: $\mathrm{As}, \mathrm{Ba}, \mathrm{Bi}, \mathrm{Br}, \mathrm{Ce}, \mathrm{Co}, \mathrm{Cr}, \mathrm{Cu}$, $\mathrm{Ga}, \mathrm{Hf}, \mathrm{La}, \mathrm{Mo}, \mathrm{Nb}, \mathrm{Ni}, \mathrm{Pb}, \mathrm{Rb}, \mathrm{Sr}$, Th, U, V, Y, Zn, Zr oraz Cd i Sn, zbadano (w próbkach proszkowych prasowanych) spektrometrem Philips PW 2400. Stratę prażenia oznaczono metodą wagową. Natomiast zawartość pierwiastków ziem rzadkich: Ce, Dy, Er, Eu, Gd, Ho, La, Lu, Nd, Pr, Sm, $\mathrm{Tb}, \mathrm{Tm}, \mathrm{Yb}, \mathrm{Sc}, \mathrm{Y}$ i Th, określono metodą spektrometrii mas $\mathrm{z}$ jonizacją w plazmie indukcyjnie sprzężonej (ICP-MS).

\section{PRZEGLAD BADAŃ MINERALIZACJI REE W KARBONATYTACH REJONU TAJNA}

W badaniach masywu Tajna można wyróżnić kilka etapów. W latach 60. XX w. wykonano otwory Tajno IG 1, 2, 3,5 i 6 oraz wyjaśniono znaczenie anomalii geofizycznych (Gaczyński, Szymański, 1967). W pierwszym odwierconym otworze natrafiono na zbrekcjowane, ciemne skały

\footnotetext{
${ }^{1}$ Państwowy Instytut Geologiczny - Państwowy Instytut Badawczy, ul. Rakowiecka 4, 00-975 Warszawa; witold.dymowski@pgi.gov.pl
} 
magmowe typu piroksenitów, z dużą ilością żył, trudne do makroskopowego opisu. Dopiero na podstawie wyników szczegółowych badań mineralogiczno-petrograficznych i chemicznych uznano je za karbonatyty ze znacznie podwyższoną zawartością REE. Odwiercenie kolejnych otworów, według pierwotnego planu, umożliwiło określenie granic anomalii, ale stwierdzono znacznie mniejszą zawartość REE. W efekcie tych prac odkryto mineralizację karbonatytową, która jest nośnikiem pierwiastków ziem rzadkich. Określono również jej zasięg i zmienność.

Na początku lat 90. XX w. opracowano koncepcję kolistej struktury komina wulkanicznego ze sztokwerkiem karbonatytowym (Cieśla i in., 1990). Przyjęcie takiego założenia umożliwiło precyzyjne wskazanie lokalizacji nowych wierceń,

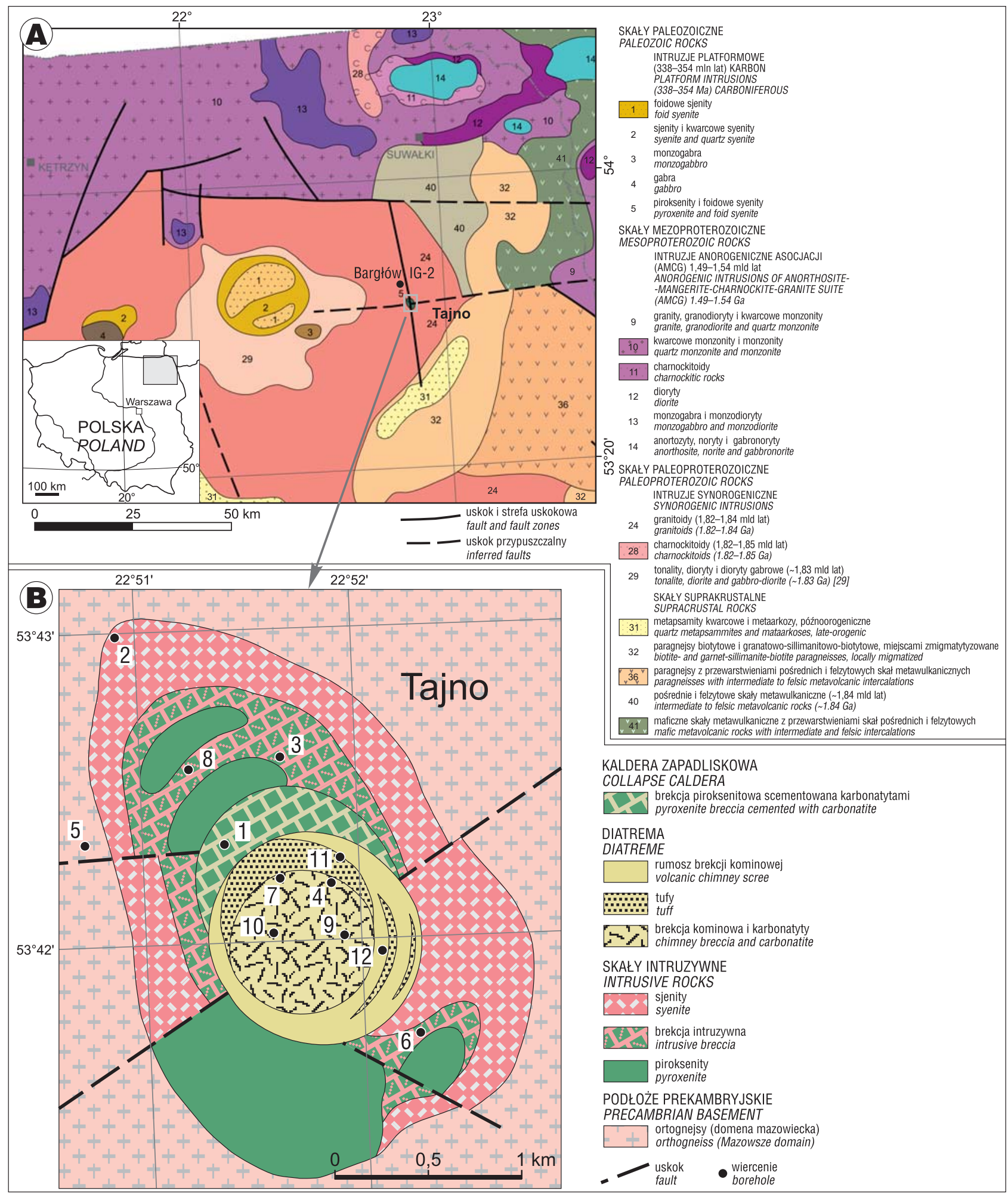

Ryc. 1. Mapa geologiczna masywu Tajna i sąsiadującego z nim fragmentu platformy wschodnioeuropejskiej: A - wg Krzemińskiej i in., 2017; B - wg Wiszniewskiej i in., 2020

Fig. 1. Geological map of the Tajno Massif and the adjacent area of the East European Platform: A-after Krzemińska et al., 2017; B - after Wiszniewska et al., 2020 


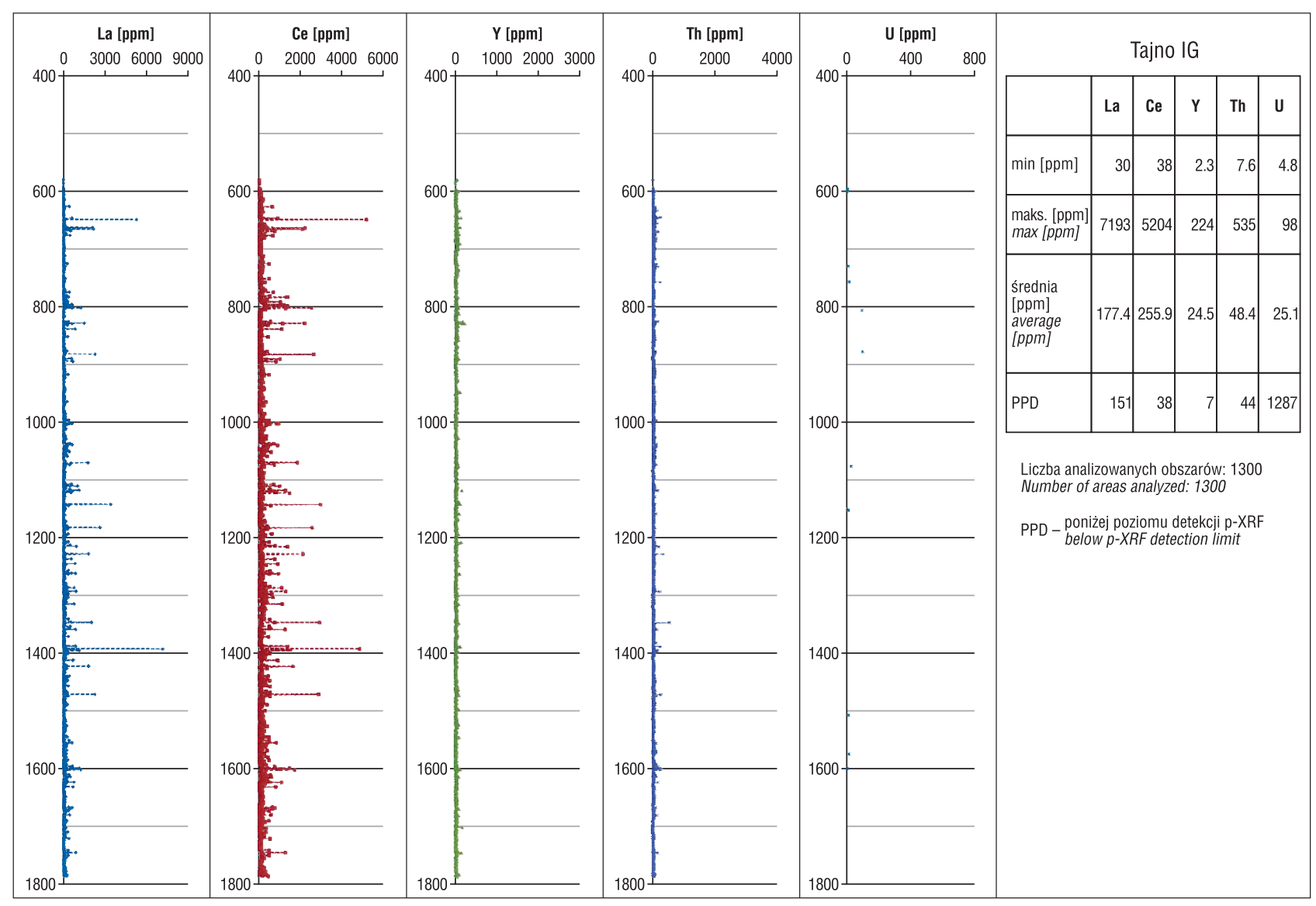

Ryc. 2. Zawartość La, Ce, Y, Th i U w skałach podłoża krystalicznego (XRF) w otworze Tajno IG 4 (Pańczyk-Nawrocka i in., 2015) Fig. 2. Contents of La, Ce, Y, Th and U in rocks (XRF) of the crystalline basement of the Tajno Massif in the Tajno IG 4 borehole (Pańczyk-Nawrocka et al., 2015)

które dużo skuteczniej trafiały w mineralizację (Ryka, 1992). Wykonano otwory: Tajno IG 4, 7, 8 i 10, a następnie Tajno IG 9, 11 i 12, którymi okonturowano złoże, oraz udokumentowano i obliczono jego zasoby REE. Okazało się, że najbogatsze w REE są profile wierceń Tajno IG 4 i Tajno IG 10 o sumarycznej miąższości stref zmineralizowanych (odpowiednio) 31,08 oraz 34,22 m i średniej zawartości sumy pierwiastków ziem rzadkich (przedstawianej w formie tlenkowej) - 0,41 i $0,34 \% \mathrm{TR}_{2} \mathrm{O}_{3}$. W profilach pozostałych otworów złożowych stwierdzono występowanie interwałów o następującej zawartości REE: Tajno IG 7 $>6,73 \mathrm{~m} ; 0,81 \% \quad \mathrm{TR}_{2} \mathrm{O}_{3}$; Tajno IG $11>2,76 \mathrm{~m} ; 0,74 \%$ $\mathrm{TR}_{2} \mathrm{O}_{3}$; Tajno IG $1>9,96 \mathrm{~m} ; 0,30 \% \mathrm{TR}_{2} \mathrm{O}_{3}$. Największą zawartość sumy REE osiagają w stosunkowo cienkich żyłach karbonatytowych - 1,5\%; 1,95\%; 1,96\%, max. $2,7 \% \mathrm{TR}_{2} \mathrm{O}_{3}$ (Kabata-Pendias i in., 1988, 1989). Najczęściej zaś mieszczą się w przedziale $0,3-0,6 \%$. Obliczono, że powierzchnia złoża Tajno wynosi $0,216 \mathrm{~km}^{2}$, średnia zawartość REE w interwałach złożowych - 0,37\%, a sumaryczne zasoby - ok. 34000 t REE (Kubicki, 1992). Niestety, prawie połowa zasobów zalega poniżej 1000 m p.p.t.

W połowie drugiej dekady XXI w. przeprowadzono nowoczesne badania przesiewowe wybranych pierwiastków REE (La, Ce, Y, Th i U) w rdzeniach wiertniczych z obszaru platformy wschodnioeuropejskiej. Do badań użyto ręcznego skanera XRF Olympus Delta 50 Premium. Wykonano 16310 pomiarów (w tym 8599 rdzeni z masywu Tajna), które skalibrowano 200 analizami ICP-AES MS z pełnym zakresem REE (La-Lu) - aż 102 analizy doty- czyły rejonu Tajna (Pańczyk-Nawrocka i in., 2015). Największą zawartość Ce i La odnotowano w rdzeniu skalnym z otworu Tajno IG 4 (ryc. 2). Na wykresach normalizowanych względem prymitywnego płaszcza (ryc. 3) stwierdzono ciekawą zależność pomiędzy zawartością pierwiastków ziem rzadkich w skałach podłoża krystalicznego rejonu Tajna oraz otaczających mineralizację REE. Na wykresach tych widać grupowanie się charakterystycznych krzywych, obrazujące zapewne zależności genetyczne skał. Krzywe ukazujące zawartość REE w profilach otworów złożowych Tajno IG 1, 4, 7, 9, 10 i 11 są silniej nachylone w części LREE, co wskazuje na znaczne zwiększenie koncentracji La i Ce. Mineralizację REE odnotowano w skałach, które podlegały oddziaływaniu dolnokarbońskich procesów wulkanicznych (Wiszniewska i in., 2020). Lokalnie wzbogacenia w REE mają znaczenie złożowe. Profilom skał z otworów Tajno IG 6 i IG 8, w których nie występują skały wulkaniczne, a jedynie stare brekcje intruzywne, odpowiadają wykresy REE bardziej spłaszczone w części LREE i miejscami bardziej zagęszczone - jednorodne.

Od kilku lat są prowadzone szeroko zakrojone prace nad oceną potencjału złożowego REE w Polsce, w tym także na platformie wschodnioeuropejskiej i w skałach krystalicznych masywu Tajna (Mikulski i in., 2018, 2021). Określono pozycję i znaczenie masywu Tajna na geologicznym tle platformy wschodnioeuropejskiej (Krzemińska $\mathrm{i}$ in., 2017) oraz ustalono wiek skał plutonicznych i wulkanicznych odpowiedzialnych za mineralizację REE (Wiszniewska $\mathrm{i}$ in., 2020). 


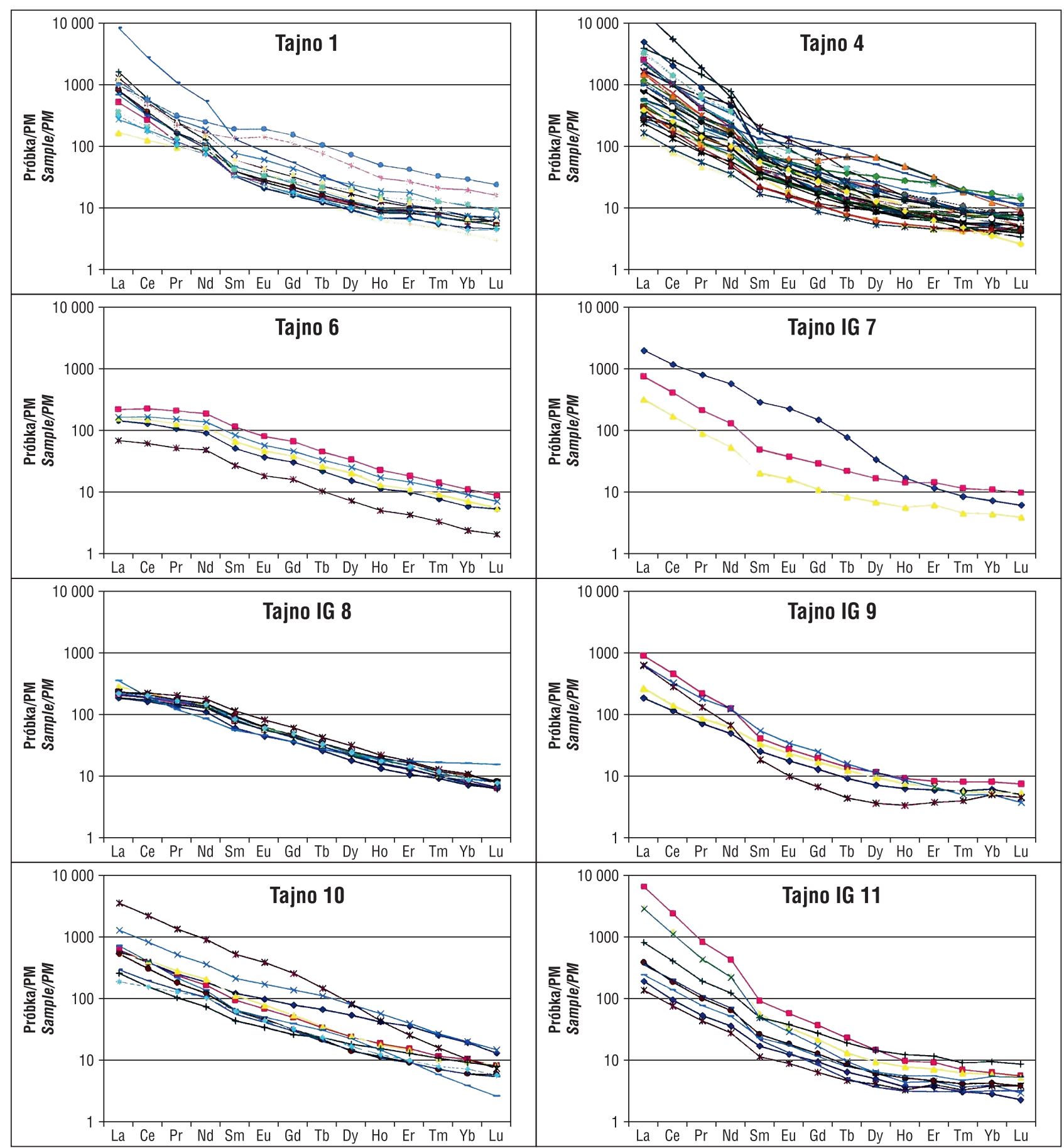

Ryc. 3. Zawartość REE w próbkach skał podłoża krystalicznego rejonu Tajna, standaryzowana według prymitywnego płaszcza (wg Pańczyk-Nawrocka i in., 2015)

Fig. 3. Primitive mantle-normalized trace element abundance patterns in rocks of the crystalline basement of the Tajno Massif (after Pańczyk-Nawrocka et al., 2015)

\section{WCZEŚNIEJSZE BADANIA ZWIETRZELIN SKAL KRYSTALICZNYCH}

Badania geochemiczne zwietrzelin skał podłoża krystalicznego masywu Tajna przeprowadziła Kabata-Pendias (1988, 1990). Analizie poddano wówczas 63 próbki z rdzeni otworów Tajno IG 4, 7, 9, 10 i 11, które pobrano w kolejności od skały macierzystej słabo zmienionej, poprzez zwietrzelinę, kończąc na osadowych skałach nadkładu należących do dolnego triasu. Analizy chemiczne składników głównych $\left(\mathrm{Fe}_{2} \mathrm{O}_{3}, \mathrm{FeO}, \mathrm{CaO}, \mathrm{MgO}, \mathrm{K}_{2} \mathrm{O}, \mathrm{Na}_{2} \mathrm{O}\right.$ i TiO $\left.{ }_{2}\right)$ uzupełniono oznaczeniami wybranych pierwiastków śla- dowych: $\mathrm{Co}, \mathrm{Cr}, \mathrm{Cu}, \mathrm{Ni}, \mathrm{Zn}$ i V. Wykonano także analizy sumy $\mathrm{TR}_{2} \mathrm{O}_{3}$ w rdzeniach z otworów Tajno IG 4, 7, $10 \mathrm{i} 12$. Na podstawie wyników badań rentgenostrukturalnych zwietrzelin potwierdzono obecność w nich następujących minerałów ilastych: montmorylonitu, kaolinitu, illitu i chlorytu, hydromik oraz minerałów towarzyszących: syderytu, goethytu, skalenia, kwarcu, czasem też piroksenów i dolomitu (Kabata-Pendias, 1988, 1990).

W stosunkowo cienkiej (kilku-, kilkunastometrowej) pokrywie zwietrzelinowej skał plutonicznych nie stwierdzono znacznych przeobrażeń skał, które mogłyby spowodować wyraźne przemieszczenie pierwiastków chemicznych 


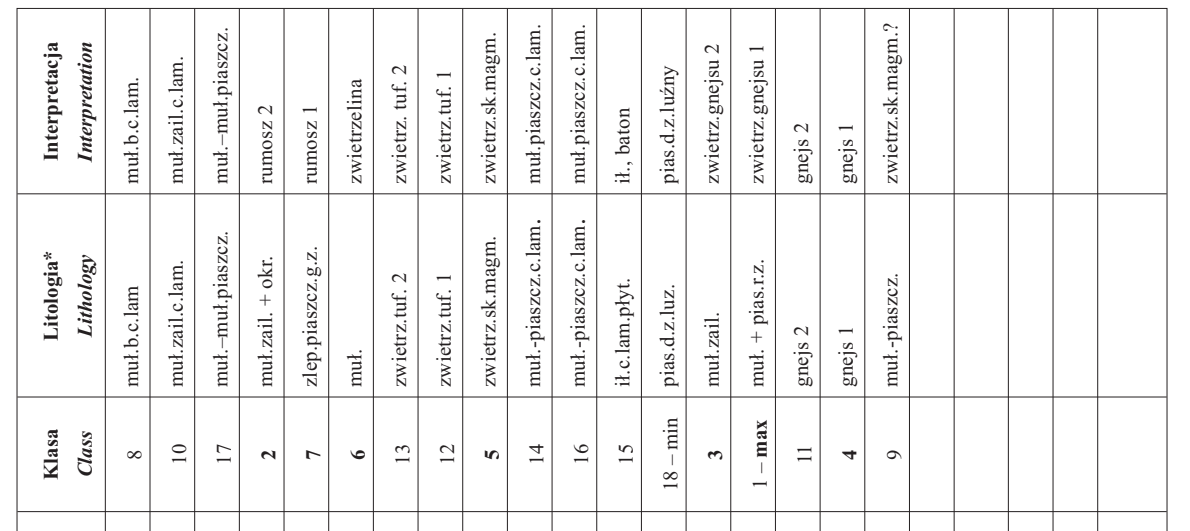

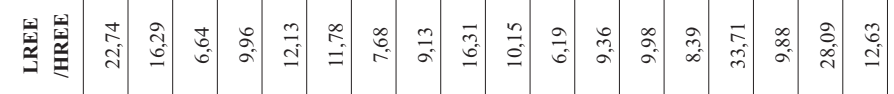

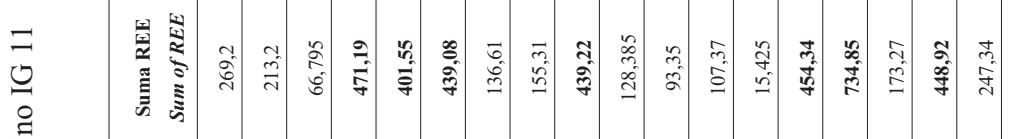

高

in

$\underline{0}$

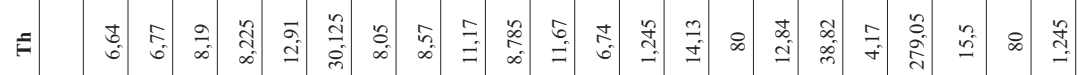

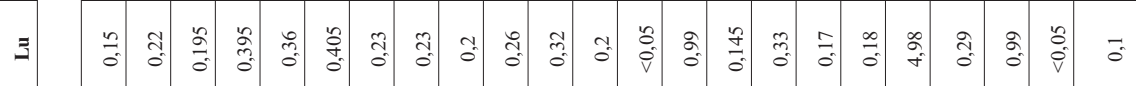

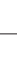

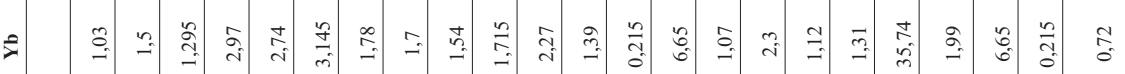

$\underline{0}$

舀

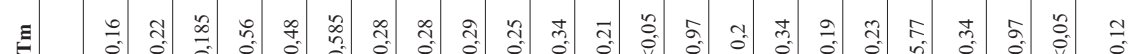

चुँ

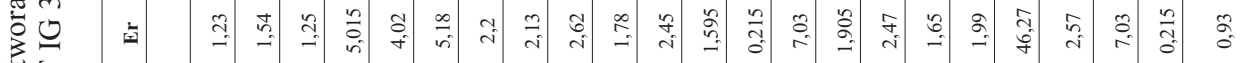

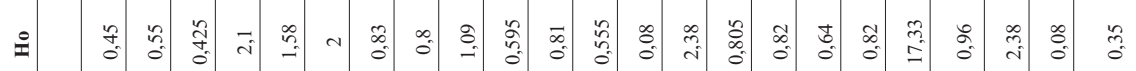

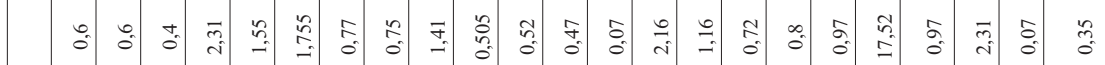

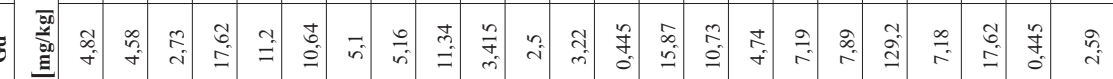

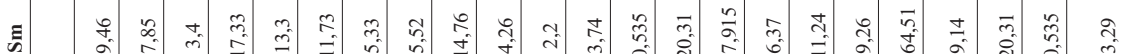

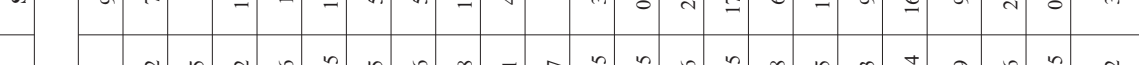

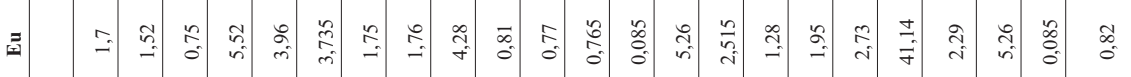

₹

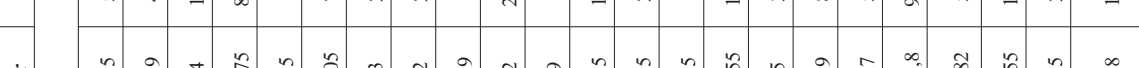

$=$ =

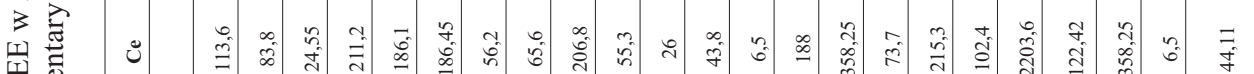

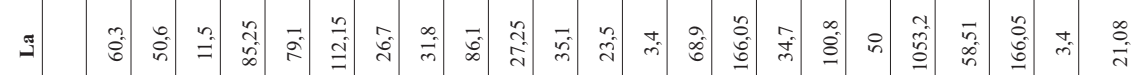

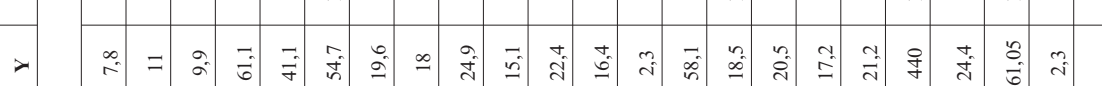

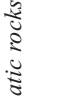


(Kabata-Pendias, 1988, 1990). Średnio rozwinięte procesy wietrzeniowe nie zatarły składu chemicznego skał macierzystych, co wskazuje na brak migracji pierwiastków i świadczy o małej ilości roztworów krążących w zwietrzelinie (Kabata-Pendias, 1988, 1990). Lokalny, słaby rozwój czapy żelaznej, w postaci skupień syderytu czy goethytu, wskazuje na dominację warunków redukcyjnych (Kabata-Pendias, 1988, 1990).

Wśród minerałów wtórnych, powstałych w wyniku wietrzenia alkaliczno-ultrazasadowego masywu Tajna, dominują minerały ilaste o pakietach mieszanych - typu montmorylonitu. Kaolinit i hydromiki mają znaczenie podrzędne. Na podstawie analizy zawartości sumy pierwiastków ziem rzadkich $\mathrm{w}$ rdzeniach $\mathrm{z}$ otworów wiertniczych nie zaobserwowano wyraźnej regularności w rozmieszczeniu REE w profilu wietrzeniowym. W stosunku do skał macierzystych: piroksenitów, syenitów i foidaitów, stwierdzono w nim natomiast znaczne zubożenie w pierwiastki śladowe (Krystkiewicz, Krzemiński, 1992). W zwietrzelinie skał krystalicznych z otworu Tajno IG 4 uznanego za jeden z najbardziej obiecujących złożowo zawartość sumy REE waha się w granicach 0,024-0,108\%, co w porównaniu do średniej zawartości REE w karbonatytach oznacza wielokrotne (ok. 20-50-krotne) zubożenie. Zawartość REE w próbkach litego piroksenitu oraz jego zwietrzeliny, pobranych z rdzenia interesującego złożowo wiercenia Tajno IG 10, utrzymuje się na poziomie tła geochemicznego. Zdarza się też, że w rdzeniach otworów ubogich pod względem złożowym (np. Tajno IG 12) brunatna zwietrzelina jest wzbogacona w żelazo i dwukrotnie bogatsza w $\mathrm{TR}_{2} \mathrm{O}_{3} \mathrm{w}$ porównaniu ze świeżym tufitem.

Ciekawym przykładem rozpraszania REE w zwietrzelinach jest profil otworu Tajno IG 7, w którym syenit (świeży i słabo przeobrażony) jest nieco wzbogacony w REE (zawiera 0,$25 ; 0,34 \% \mathrm{TR}_{2} \mathrm{O}_{3}$ ); zwietrzeliny ze znaczną ilością montmorylonitu (barwy brunatnej) są kilkakrotnie zubożone $\left(0,06 ; 0,08 \% \mathrm{TR}_{2} \mathrm{O}_{3}\right)$, a zwietrzeliny o barwie jasnoszarej są jedynie dwukrotnie zubożone w REE $(0,17$; $0,19 \% \mathrm{TR}_{2} \mathrm{O}_{3}$ ). Może to zależy od ilości i proporcji odpowiednich minerałów ilastych, które mogą się przyczyniać do kumulowania REE poprzez selektywną sorpcję na powierzchni minerałów pakietowych.

\section{WYNIKI BADAŃ WTÓRNEJ MINERALIZACJI REE W NADKLADZIE SKAL ALKALICZNYCH MASYWU TAJNA I DYSKUSJA}

W badanych próbkach zwietrzelin i skał nadkładu masywu krystalicznego Tajna, pochodzących z profili otworów Tajno IG 3, 5 i 11, są obecne następujące pierwiastki REE (malejąco): Ce, La, Nd, Sc, Y, Th, Pr, Sm, Gd, Dy, Er, Eu, $\mathrm{Yb}, \mathrm{Tb}, \mathrm{Ho}, \mathrm{Tm}$ i Lu (tab. 1). W utworach tych znacznie dominują pierwiastki lekkich ziem rzadkich (LREE - szeregu La-Sm) - ich udział w sumie REE wynosi prawie 93\% (4643,3 ppm). Pierwiastki ciężkie (HREE - szeregu Gd-Lu) stanowią jedynie ok. 7\% (352,1 ppm) sumy REE. Cer, którego jest najwięcej, stanowi prawie połowę sumy REE. Razem z lantanem, którego jest dwa razy mniej, jego udział w sumie REE wynosi przeszło 65\%. Lantanu jest nieco więcej niż neodymu. Udziały tych pierwiastków w sumie REE różnią się jeszcze mniej, a ich sumaryczna zawartość jest zbliżona, choć nieco mniejsza od zawartości dominującego ceru. Spośród LREE najmniej jest europu ( $0,82 \%$ udziału w REE), choć nie we wszystkich próbkach jest czytelna ujemna anomalia Eu. Wśród ciężkich pier- wiastków ziem rzadkich (HREE) - najwięcej jest gadolinu $(2,59 \%$ udziału), a najmniej lutetu $(0,1 \%)$ i tulu $(0,12 \%)$.

Wzbogacenie w REE (stosunek maksymalnej zawartości do średniej) zmienia się od 2,2 (Sm), 2,3 (Eu) do 2,84 (La), 2,85 (Tm) i 2,93 (Ce). Jeszcze większe wzbogacenie osiągają Yb $(3,34)$ i Lu $(3,4)$, ale ze względu na ich niewielką zawartość $\mathrm{w}$ próbkach - na pograniczu błędu pomiaru - wyniki te są traktowane jako watpliwe. Średnie frakcjonowanie LREE/HREE wynosi 13,14. Jego wartość zmienia się od 6,19 do 33,71 i tylko wyjątkowo jest pozytywnie skorelowana z sumą REE. Może to wynikać z niewielkich stężeń HREE, często zbliżonych do progu wykrywalności pierwiastków.

Anomalie sumy REE są nieregularnie rozmieszczone w profilach skalnych analizowanych otworów wiertniczych. Nie występuje prosta zależność koncentracji REE od odległości do skał krystalicznych lub ich zwietrzelin (tzn. do spagu pokrywy skał osadowych). Wyraźna jest natomiast zależność zawartości REE od litologii skał osadowych. Partie skał wzbogaconych w REE (występujące niekoniecznie w spągu części osadowej) przeplatają się z wyraźnie zubożonymi.

Maksymalne sumy REE oznaczono w 6 próbkach skał pochodzących ze środkowej części profilów (w tab. $1 \mathrm{w}$ kolumnie Klasa oznaczono je grubszą czcionka). Najwięcej REE (śr. ok. 400-470 ppm, max 735 ppm) zawieraja skały silnie zwietrzałe, które przeobraziły się w rumosze, czasami ze słabo czytelnymi okruchami skał krystalicznych, oraz zwietrzeliny mułowcowo-piaszczyste po gnejsie, pozostałe bez przemieszczenia w pobliżu skał wyjściowych. Największą koncentrację pierwiastków ziem rzadkich, w tym $\mathrm{Ce}$, La i Nd, stwierdzono w próbce T5/4 (w tab. 1 oznaczonej jako klasa 1).

Względne wzbogacenie w REE wykryto w gnejsach z otworu Tajno IG 5 (próbka T-5/6 - klasa 4), a jeszcze większe w ich zwietrzelinach (T-5/3 - klasa 3), a także w zwietrzelinach skał magmowych (T-11/9 - klasa 5). Stwierdzono zatem, że koncentracje REE zależą od litologii skał, a także od tego czy zostały przeobrażone przez procesy wulkaniczne i w związku z tym zawierają żyłki karbonatytowe, które mogą być nośnikami REE.

Skały osadowe, m.in. mułowce i mułowce piaszczyste, z warstwowaniem i laminacją, które świadczą o transporcie materiału, są zubożone w REE (zawierają 70-160 ppm REE; w tab. 1 oznaczono je jako klasy 12-18). Mało REE zawierają także próbki zwietrzałego tufitu. Najmniejszą sumę zawartości REE (ok. 15 ppm) oznaczono w górnej części profilu osadowego, w luźnym, sypkim, jasnym piaskowcu drobnoziarnistym, dość dobrze wysortowanym (próbka T5/2 - klasa 18). Możliwe, że jest to piaskowiec jurajski, usytuowany w profilu poniżej iłów batonu (T-5/1 - klasa 15). W próbkach tej skały zawartość prawie wszystkich pierwiastków ziem rzadkich jest bardzo mała, wręcz bliska progu wykrywalności. Na podstawie wyników analizy chemicznej głównych składników skały stwierdzono, że jest to prawie czysty chemicznie piaskowiec o zawartości ok. $85 \% \mathrm{SiO}_{2}$, nie posiadający spoiwa.

W zwietrzelinach stropu krystaliniku stwierdzono większe wzbogacenie w pierwiastki REE niż w analizowanych próbkach skał pokrywy osadowej (Kabata-Pendias, 1988, 1990). Zwietrzeliny te zawierają zwykle więcej okruchów skał podłoża lub rumosze. Do wyjątków należą wzbogacenia w zwietrzelinach drobnoziarnistych - np. mułowcach i mułowcach piaszczystych, które mogą zawierać nieco więcej minerałów ilastych. 


\section{$\rightarrow$}

Ryc. 4. Zawartość REE w próbkach skał pokrywy osadowej rejonu Tajna (Tajno IG 3; IG 5 i IG 11), standaryzowana wg chondrytu

Fig. 4. Chondrite-normalized REE abundance patterns in rocks of the sedimentary cover of the Tajno Massif (Tajno IG 3; IG 5 and IG 11)

W stosunku do skał podłoża krystalicznego, zawierających żyły karbonatytowe i rozproszoną mineralizację REE, w pokrywie osadowej masywu Tajna następuje wyraźne zróżnicowanie na obszary o podwyższonej koncentracji pierwiastków ziem rzadkich w diatremie karbońskiej oraz 8-9-krotne zubożenie wokół niej. Średnia zawartość REE w skałach nadkładu mezozoicznego nie odbiega znacznie od średniej w skałach krystalicznych otoczenia złoża karbonatytowego. Różni się zaś wyraźnie w zależności od litologii skał mezozoicznych. Wyraźne zubożenie w REE postępuje wraz ze wzrostem przemycia osadów i zmniejszeniem ilości spoiwa ilasto-mułowcowego. Najmniejszą zawartość REE stwierdzono w luźnych, wysortowanych, jasnych piaskowcach drobnoziarnistych.

Z wykresów zawartości REE w próbkach skał pokrywy osadowej masywu Tajna (ryc. 4), przeliczonych względem chondrytu, można odczytać, że skały te zawierają mniej pierwiastków ziem rzadkich niż karbonatyty. Niewielkie pochylenie wykresów na odcinku LREE (Ce, La) oraz zgrupowanie krzywych mogą świadczyć o względnej jednorodności próbek pod względem zawartości REE. Zbiór próbek z otworu Tajno IG 11 jest bardziej złożony, zawiera dwie generacje próbek o różnym pochyleniu wykresów. Odbiega od nich wykres próbki Tajno IG 11/11, na którym widać silny ubytek Ce. Drugim wyjątkiem jest próbka IG 5/3 z pokaźnym wzbogaceniem w HREE i spadkiem zawartości La. Na wykresie zawartości REE (ryc. 4) wyraźnie zaznaczają się zubożenia - np. odstaje krzywa obrazująca mniejszą o rząd wielkości zawartość REE w próbce luźnego piaskowca (Tajno IG 5/2) i iłu batońskiego (Tajno IG 5/1) oraz lokalny, wyraźny niż Eu. Przebieg wykresów zawartości REE w próbkach skał pokrywy osadowej masywu Tajna przypomina podobne krzywe odzwierciedlające koncentracje REE w brekcji intruzywnej w podłożu krystalicznym (otwory Tajno IG 6 i 8).

\section{WNIOSKI}

1) W zwietrzelinach i skałach mezozoicznej pokrywy osadowej masywu Tajna nie stwierdzono wtórnego wzbogacenia w pierwiastki REE, pomimo ich nagromadzenia o znaczeniu złożowym w żyłach karbonatytowych i impregnacjach brekcji intruzywnych, a także w piroksenitach oraz wulkanicznych brekcjach kominowych w podłożu krystalicznym.

2) Prawdopodobne jest, że koncentracja pierwiastków ziem rzadkich nastąpiła w utworach zawierających minerały ilaste, $w$ tym ich specyficzne mieszaniny.
Tajno IG-11
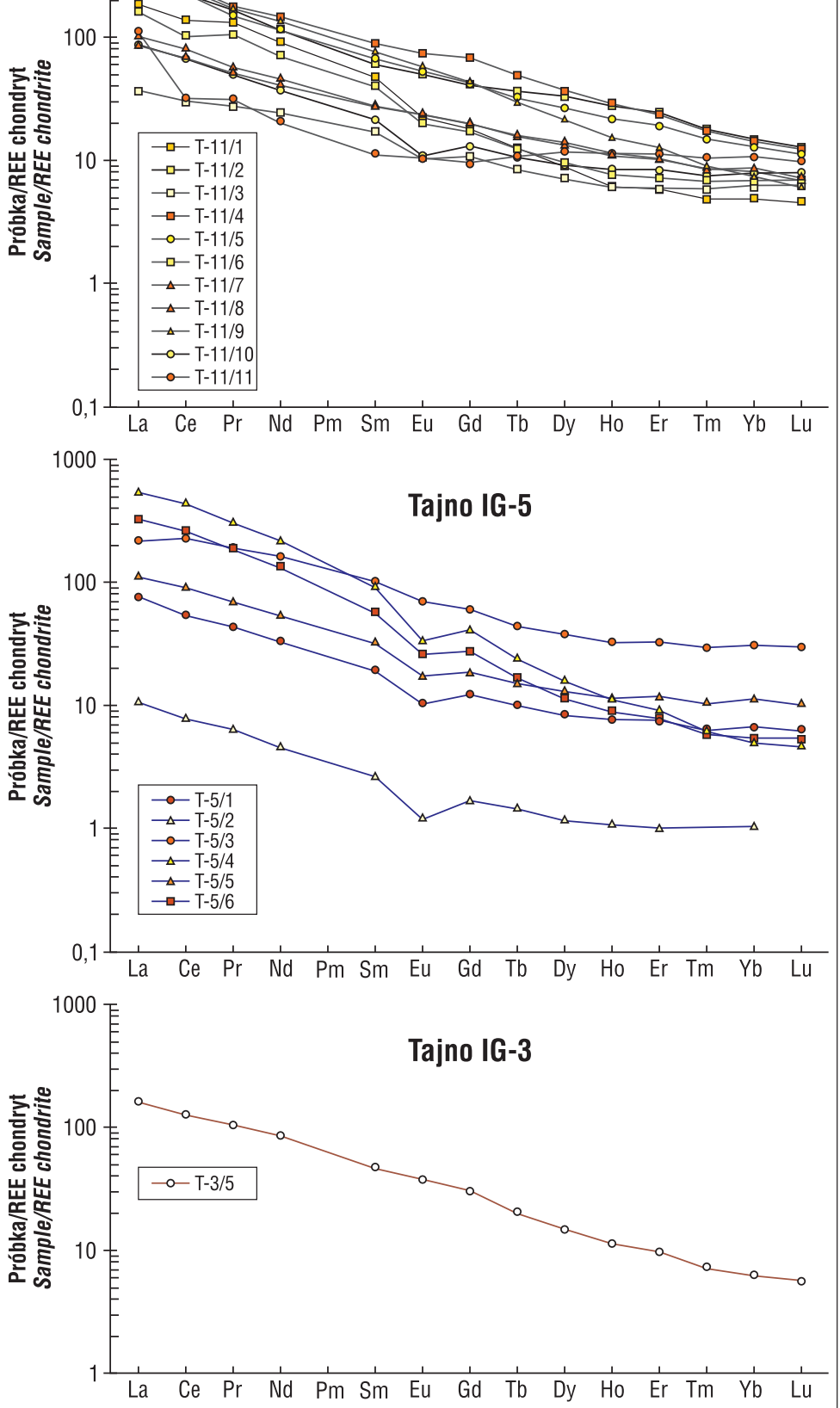

3) Jako potencjalne miejsca kumulowania się pierwiastków REE można rozpatrywać lokalne obniżenia powierzchni erozyjnych w rejonach denudacji platform krystalicznych lub na obrzeżających je obszarach jeziorzysk, równi aluwialnych, rzek roztokowych, plaż płytkich zbiorników śródlądowych czy płytkich mórz.

4) Nie można też wykluczyć występowania płatów, soczew czy innych nieregularnych ciał ilastych, które mogły zaabsorbować pierwiastki ziem rzadkich uwolnione w trakcie wietrzenia krystalicznych skał masywu Tajna w bezpośrednim sąsiedztwie analizowanych otworów wiertniczych.

5) W toku dalszych badań należałoby wykonać analizę sedymentologiczną skał pokrywy osadowej masywu Tajna, w celu poznania stopnia przemycia osadów i rozpoznania obszarów kumulowania się minerałów ilastych, ponieważ kumulacje te mogą zawierać lokalne koncentracje pierwiastków REE. 
Prace własne, a zwłaszcza pomiary zawartości REE przeprowadzono w ramach realizacji tematu Trójwymiarowe modelowanie geologiczne struktury Masywu Tajna pod katem określenia możliwości występowania pierwotnej $i$ wtórnej mineralizacji REE w skałach alkalicznych i ich nadkładzie. Dziękuję za wsparcie Zdzisławowi Peteckiemu prowadzacemu ten temat oraz Annie Grabarczyk za wykonanie wykresów REE. Wyrazy wdzięczności składam recenzentom - prof. Katarzynie Jarmołowicz-Szulc i dr Pawłowi Kwecko - za cenne uwagi.

\section{LITERATURA}

CIEŚLA E., KABATA-PENDIAS A., KRYSTKIEWICZ E., KRZEMIŃSKI L., KUBICKI S., MARCINKOWSKI B., RYKA W. 1990 Centralny Program Badawczo-Rozwojowy nr 1.8., Budowa geologiczna Polski i poszukiwania złóż surowców mineralnych. Cel nr 14. Ocena zasobów perspektywicznych rud pierwiastków ziem rzadkich w rej. Tajna i Moniek. Punkt kontrolny nr 04. Dokumentacja geologiczna rejonu Tajna wraz z oceną zasobów perspektywicznych. Arch. NAG PIG, Warszawa, $\mathrm{nr}$ 502/91

GACZYŃSKI B., SZYMAŃSKI B. 1967 - Badanie anomalii Tajna. Arch. NAG PIG, Warszawa, nr 3336/76.

KABATA-PENDIAS A., KRYSTKIEWICZ E., KUBICKI S., KURBIEL H., MARCINKOWSKI B., RYKA W., SZYMKOWIAK A., BORZĘCKI J. CZARNOCKI A., MIZERACKA K. 1988 - Centralny Program Badawczo-Rozwojowy nr 1.8., Budowa geologiczna Polski i poszukiwania złóż surowców mineralnych. Cel $\mathrm{nr}$ 14. Ocena zasobów perspektywicznych rud pierwiastków ziem rzadkich w rej. Tajna i Moniek. Punkt kontrolny nr 01. Opracowanie wyników otworów Tajno IG 4, 7, 8, 10. Arch. NAG PIG, Warszawa, nr 499/91.

KABATA-PENDIAS A., KUBICKI S., KRYSTKIEWICZ E., KRZEMIŃSKI L., MARCINKOWSKI B., RYKA W. 1989 - Centralny Program Badawczo-Rozwojowy nr 1.8. Budowa geologiczna Polski i poszukiwania złóż surowców mineralnych. Cel nr 14. Ocena zasobów perspektywicznych rud pierwiastków ziem rzadkich w rej. Tajna i Moniek. Punk kontrolny nr 02. Opracowanie wyników otworów Tajno IG 9, 11, 12 Arch. NAG PIG, Warszawa, nr 501/91.
KRYSTKIEWICZ E., KRZEMIŃSKI L. 1992 - Petrology of the alkaline-ultrabasic Tajno massif. Pr. Państw. Inst. Geol., 139: 19-35.

KRZEMIŃSKA E., KRZEMIŃSKI L., PETECKI Z., WISZNIEWSKA J., SALWA S., ŻABA J., GAIDZIK K., WILLIAMS I.S., ROSOWIECKA O., TARAN L., JOHANSSON C., PÉCSKAY Z., DEMAIFFE D., GRABOWSKI J., ZIELIŃSKI G. 2017 - Mapa geologiczna podłoża krystalicznego polskiej części platformy wschodnioeuropejskiej 1:1000 000. Państw. Inst. Geol.-PIB.

KUBICKI S. 1992 - An outline of geological structure of the Tajno massif. Pr. Państw. Inst. Geol., 139: 7-13.

MIKULSKI S.Z., OSZCZEPALSKI S., SADŁOWSKA K., CHMIELEWSKI A., MAŁEK R. 2018 - Wysteppowanie pierwiastków towarzyszących i krytycznych w wybranych udokumentowanych złożach rud $\mathrm{Zn}-\mathrm{Pb}, \mathrm{Cu}-\mathrm{Ag}, \mathrm{Fe}-\mathrm{Ti}-\mathrm{V}, \mathrm{Mo}-\mathrm{Cu}-\mathrm{W}, \mathrm{Sn}, \mathrm{Au}-\mathrm{As}$ i Ni w Polsce. Biul. Państw. Inst. Geol., 472: 21-52.

MIKULSKI S.Z., MAŁEK R., CHMIELEWSKI A., SADŁOWSKA K., BRAŃSKI P., OSZCZEPALSKI S., MARKOWIAK M., PIEŃKOWSKI G., ZGLINICKI K., WISZNIEWSKA J., DYMOWSKI W., WOŁKOWICZ S., ZIELIŃSKI G., GIRO L., LECH D., GÓRECKA E., KARMASZ D. 2021 - Ocena potencjału złożowego REE w Polsce. Arch. NAG PIG-PIB, Warszawa.

PAŃCZYK-NAWROCKA M., BAZARNIK J., GIRO L., PACZEŚNA J., ZIELIŃSKI G., NAWROCKI J., KRZEMIŃSKA E., ROSOWIECKA O., KRZEMIŃSKI L., LAMPART P., LENARCZYK M., IWASIŃSKA-BUDZYK I. 2015 - Ocena zawartości metali ziem rzadkich (REE) w alkalicznych skałach magmowych kratonu wschodnioeuropejskiego i ich pokrywie osadowej metodą skanowania XRF rdzeni wiertniczych. Arch. NAG PIG, Warszawa, nr 4154/2016.

RYKA W. 1992 - Geology of the Tajno massif carbonatites (northestern Poland). Pr. Państw. Inst. Geol., 139: 43-78.

RYKA W., ARMBRUSTMACHER T.J., MODRESKI P.J. 1992 - Geochemistry and petrology of the alkaline intrusive rocks of the Tajno massif (preliminary report). Pr. Państw. Inst. Geol., 139: 37-43.

WISZNIEWSKA J., PETECKI Z., KRZEMIŃSKA E., GRABARCZYK A., DEMAIFFE D. 2020 - The Tajno ultramafic-alkaline-carbonatite massif, NE Poland: a review. Geophysics, petrology, geochronology and isotopic signature. Geol. Quart., 64 (2): 402-421.

ZNOSKO J. 1993 - Jak odkryto suwalskie magnetyty. Prz. Geol., 41: $552-558$.

Praca wpłynęła do redakcji 16.03.2021 r.

Akceptowano do druku 7.05.2021 r. 